\title{
Service Quality Performance Scale in Higher Education: Culture as a New Dimension
}

\author{
Kokku Randheer ${ }^{1}$ \\ ${ }^{1}$ Department of Marketing, College of Business Administration (CBA), King Saud University (KSU), Ministry \\ of Higher Education, Saudi Arabia \\ Correspondence: Kokku Randheer, Department of Marketing, College of Business Administration (CBA), King \\ Saud University (KSU), Ministry of Higher Education, P.O. Box 71115, Riyadh 11587, Saudi Arabia. Tel: \\ 96-553-681-946. E-mail: rkokku@ksu.edu.sa or krandheer@hotmail.com
}

Received: December 15, 2014

doi:10.5539/ibr.v8n3p29
Accepted: January 7, 2015

Online Published: February 25, 2015

\begin{abstract}
SERVQUAL was modified to suit a particular study context time and again. Some researchers contented SERVQUAL's accuracy to measure service quality; others argued SERVPERF to be better scale to measure the service quality. SERVPERF was modified to measure service quality in higher education and HEdPERF evolved. HEdPERF scale was developed between 2004 through 2006 which further had to be tested under different study contexts for better validity and acceptability as done for both SERVQUAL and SERVPERF scales. This study introduced Arab cultural aspects within the existing HEdPERF scale. CUL-HEdPERF, HEdPERF, SERVPERF scales were compared using student perceptions about higher education performance. Data was analyzed using multiple regression, the calculated $\mathrm{R}^{2}, \chi^{2,}$ RMSEA, NNFI, IFI, NFI, CFI, AGFI revealed that CUL-HEdPERF scale scored better fitness to measure service quality in higher education among student perception in Saudi Arabian context than HEdPERF and SERVPERF. Fitness was tested for significance using ANOVA.
\end{abstract}

Keywords: service quality, HEdPERF, SERVPERF, higher education, culture

\section{Introduction}

Service quality is in itself a differentiator which cannot be produced at one time rather it needs a continuous practice. Service quality is a judgment defined by the consumer himself over a period of time. Service quality has received the needed research attention from both academic and industry fronts. Two and half decades of research have led to the development of SERVQUAL (Parasuraman, Zeithaml, \& Berry, 1988) and SERVPERF (Cronin \& Taylor, 1992) scales to measure the service quality. These scales have been tested under different study contexts across the industries and were modified to suit to a particular study context refer table 1 . As such higher education needed a scale and standardized.

Table 1. Scales developed to measure service quality

\begin{tabular}{lcc}
\hline Author(year) & Scale Developed & Industry \\
\hline Parasuraman et al (1988)* & SERVQUAL & General \\
Knutson et al (1991) & LODGSERV & Hospitality \\
Cronin and Taylor (1992)* & SERPERF & General \\
Getty and Thompson (1994) & LODGQUAL & Hospitality \\
Dabholkar et al. (1996) & RSQS Retail & Retail \\
Evangelos Christou and Athina Nella(1999) & SQ WINE & Wineries \\
Donald J. Shemwell and Ugur Yavas(1999) & SQ Hospitals & Hospitals \\
A. Parasuraman, Valarie A. Zeithaml, Arvind Malhotra (2005)* & ES-QUAL & Online shopping \\
(Firdaus, 2006a)* & HEdPERF & Higher Education \\
Evangelos Tsoukatos, Evmorfia Mastrojianni (2010) & BANQUAL-R metric & Banking \\
\hline
\end{tabular}

Note. *are used as reference in this study. 
In this direction (Firdaus, 2006a) had developed HEdPERF scale to measure the service quality in higher education. This scale has 41 items and the instrument has academic and non-academic components and learning service environment of the student. The scale is divided into five dimensions directed at service quality: 'Non-academic aspects'- service issues relating to students dealings and paper work with non-academic staff right from admission to the end of course. 'Academic aspects'- service issues relating to academic delivery system and necessary support from academic people. 'Reputation'- tangibility aspect which a student, parents or others stakeholders can see like facilities which generate instant image. 'Access'- service issues like approachability, ease-of contact, availability and convenience. 'Program issues'- service issues related to programs, courses, specializations, structures and health services. Higher education is the key for producing the needed workforce for any nation. Hence the quality of workforce is directly related to the service quality of designing and delivering the higher education. Since 1990's there is an increasing attention for service quality all over the world by institutions delivering higher education. Most of the institutions are in the pipeline to get accredited by international bodies like AACSB, EQUIS, IEEE which insists on achieving certain levels of service quality standards. Today the service quality issue has reached its zenith in higher education, and even there are few niche software's available like SEDONA which enable an institution to feed, maintain and manipulate information to achieve service quality from time to time. Though the service quality is well understood by many institutions involved in higher education, research in this area got less attention in developing a standardized scale of measurement and testing it across vivid higher education environments. There are few studies in this direction HEdPERF (Firdasu, 2004; 2006a) and comparative studies between SERVQUAL, SERVPERF and HEdPERF (Firdaus, 2006a; 2006b; Brochado, 2009). This study's objective is to add Arab cultural (CUL) aspects to HEdPERF scale and also to test fitness of three scales CUL-HEdPERF, HEdPERF and SERVPERF in the higher education environment of Saudi Arabia.

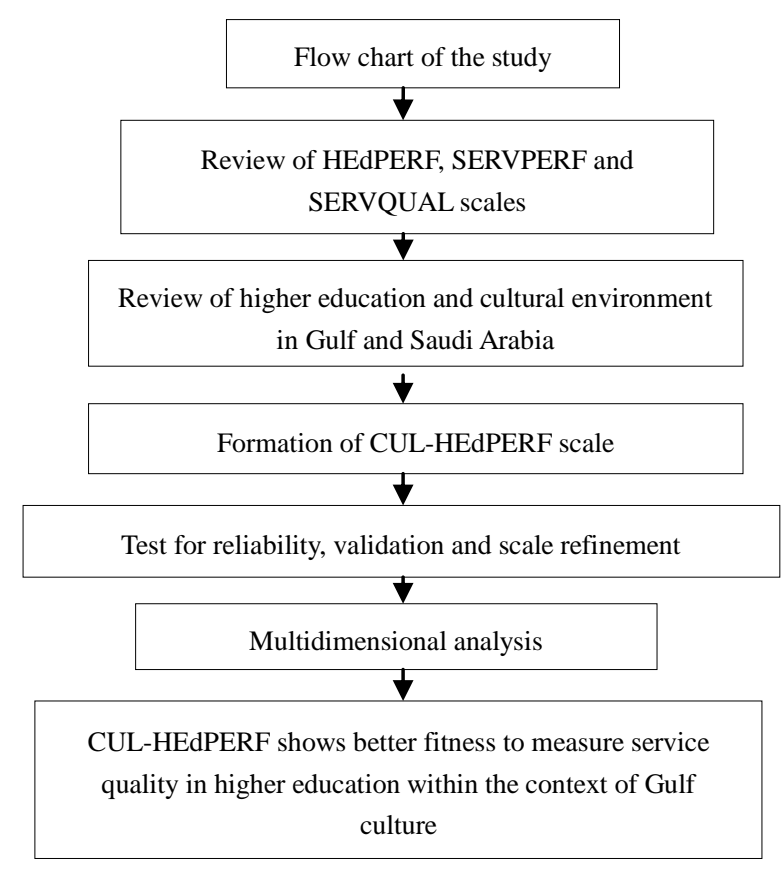

Figure 1. Flow chart explaining the study process

\section{Literature Review}

Service quality in higher education was probed by many researchers (Hill, 1995; Shank, Walker, \& Hayes, 1995; Cuthbert, 1996; Athiyaman, 1997; Yanhong \& Kaye, 1998; Oldfield \& Baron, 2000; O’Neil \& Wright, 2002; O’Neil \& Palmer, 2004; Sohail \& Shaikh, 2004; Tan \& Kek, 2004; Ginns, Prosser, \& Barie, 2007; Angell, Heffernan \& Megicks, 2008). Couple of efforts had been placed to standardize scale to measure service quality in higher education by Firdaus (2004; 2006a; 2006b; Brochado, 2009). Service quality is the gap between expectations of customers and perceptions about service delivery (Parasuraman, Zeithaml, \& Berry, 1985). Service quality scale developed by (Parasuraman et al., 1988) has five generic dimensions and 22 items which were summed-up as RATER via, responsiveness, assurance, tangibles, empathy and reliability. Though a large 
number of scales were developed to suit to different study contexts, the five dimensions of SERVQUAL served as base scale. For measuring service quality another major turnaround was given by Cronin and Taylor, 1992. They had developed SERVPERF which considered perceptions of customer's performance; unlike its predecessor SERVQUAL considers both expectations and perceptions of customers. SERVQUAL and SERVPREF faced problems like construct validity and inapplicable to different service settings, hence they needed to be modified to suit to a particular domain (Parasuraman et al., 1991; Stafford, 1999). In several service quality measurement studies done under different domains, scale refinement was done resulting in elimination and addition of some items and dimensions (Parasuraman, Zeithaml, \& Berry, 1988; Parasuraman, Berry, \& Zeithaml, 1991; Cronin \& Taylor, 1992; Stafford, 1999; Parasuraman, Zeithaml, \& Malhotra, 2005; Firdaus, 2006a). Even though SERVQUAL was refined in numerous occasions the generic scale of (Parasuraman et al., 1988) finds its importance in giving direction to past, present and future scales developed for measuring service quality.

\subsection{Testing of HEdPERF}

In addressing the issue of measuring the service quality in higher education, HEdPERF serves the best purpose. The scale was developed with 41 items across five dimensions. It was tested and validated under the context of expectations-perceptions combinations (Firdaus, 2004) assessing the difference between the two gave the gap. In the next stage HEdPERF was compared with SERVPERF and HEdPERF-SERVPERF combined scale (Firdaus, 2006b). The objective of this comparison was to test the unidimentionality, validity and reliability of each measurement scale and also refine the HEdPERF scale. Unidimentionality was proved with higher values hovering near one for all three scales using goodness of fit measures. RMSEA was also used to assess the fitness of unidimentionality and found that both SERVPERF and SERVPERF-HEdPERF combined scales showed poor fit, while HEdPERF showed a fair fitness proving right representation of population approximation. Cronbach's alpha was used for assessing the reliability. It was found that alpha values of HEdPERF dimensions were between 0.81 and 0.92, whereas for SERVPERF and HEdPERF-SERVPERF scales they were between 0.68 and 0.76 and 0.77 and 0.91 respectively. Criterion and construct validity coefficient of the scales were 0.58 and 0.57 for HEdPERF scale, 0.27 and 0.34 for SERVPERF and 0.53 and 0.57 for SERVPERF-HEdPERF scale were significant. This indicated the validity of HEdPERF displayed better validity than SERVPERF and SERVPERF-HEdPERF scales. Multiple regression analysis among the three scale's resulted HEdPERF was better scale to measure the service quality in higher education context. During the process of comparing the three scales, the original scale of HEdPERF (Firdaus, 2004) which consisted of 41 items was modified for standardization to be 38 item scale across five dimensions. A much more extensive study on measuring service quality in higher education was done by Brochado (2009), where the objective was to compare five scales namely SERVQUAL, SERVPERF, importance-weighted SERVQUAL, importance-weighted SERVPERF and HEdPERF. This study also used unidimentionality, validity, reliability and variance in comparing the scales. The findings of the study revealed that RMSEA indicator showed a fair fit status of 0.069, 0.062, 0.080, 0.056 and 0.078 for all five scales via SERVPERF, Weighted SERVPERF, SERVQUAL, Weighted SERVQUAL and HEdPERF contradicting the results achieved by Firdaus (2006b). Reliability was checked by Cronbach's alpha, all scales had higher values than the threshold value of 0.7 , HEdPERF scale alpha values were in line with study of Firdaus, 2006a. Validity was measured by the content, criterion and construct, and found that the content of the scale items had covered service quality construct in terms of higher education domain. Criterion was checked by three variables, overall satisfaction, intention of future visits and intention to recommend. It was found that all scales had significant positive correlations with the three variables. Construct validity was done by convergent validity approach which showed a high correlation between SERVPERF and HEdPERF scales. Variance was judged using $\mathrm{R}^{2}$, among the five scales, SERVPERF scale topped in explaining a variance of $48 \%$ and HEdPERF with $46 \%$.

\subsection{Higher Education}

Quality in higher education is a concern of all institutions across the world (Sohail \& Shaikh, 2004: Tan \& Kek, 2004; Angell, Heffernan, \& Angell et al., 2008). Growth in higher education is enormous due to the fact that large number of applicants joining the universities (Rugh, 2002). Participation of both private and public investment has led to an increasing interest in assessing the quality practices in higher education. Hill, 1995 says that for effective quality practices in higher education, managerial process need to be induced to implement the practice of qualitative and quantitative assessment in totality. The pressure to improve quality in higher education in Saudi Arabia is stemming from within the society and also globalization effect which is long being addressed (Cassidy \& Miller, 2002). The quality in higher education has a direct impact on student acquiring the right skills which helps him in employability. Jobs in private sector demand skills on par with times. Arab 
governments, in particular Saudi government is experiencing increasing pressure to reform curricula and teaching practices (Jamjoon, 2009). The growing numbers of unemployed graduates without sufficient skill- set is between 15-20\%. Saudi government invests considerably in higher education, 36.5 billion dollars (http://chronicle.com/article/Saudi-Arabias-Education/124771/) was allocated for the academic year 2010-11 alone to various programs of higher education in the kingdom. It became imperative to check overall quality of universities which are the platforms of higher education. To upgrade University curricula, content and teaching practices to meet student and industry needs (Cassidy \& Miller, 2002) ministry of higher education in Saudi Arabia is pushing universities to improve the quality standards. In order to oversee the overall quality improvement among universities, the government had initiated a two level accreditation achievement by universities. The first level of quality assessment is done by a national body known to be NCAAA (National Council for Academic Accreditation and Assessment) and at second level getting accredited by international bodies like AACSB, EQUIS, ABET-TAC, AACME etc. Universities are asked to provide their performance on various indicators given by national accreditation body. These indicators include academic aspects, non-academic aspects, program level details, day to day functioning, feedback from students, research outputs. Indicators measuring the quality are standards set by the accreditation bodies which will measure a particular activity against a standard. This measurement may not be a true representative of the beneficiary of this process that is student. Hence this way of indirect measurement will not contribute in wholly understanding the quality issues in higher education (O’Neil \& Wright, 2002; O’Neil \& Palmer, 2004).

Student is the most important element in measuring the quality in higher education (Hill, 1995; Anthiyaman, 1997; Oldfield \& Baron, 2000; O'Neil \& Wright, 2002; Ginns, Prosser, \& Barrie, 2007). They are the products who carry the quality aspect of the institution into the society and they can be termed as brand ambassadors. Charter for higher education, London (1993) and Hill, 1995 had defined students as customers/consumers. The concept of consumerism, customization, customer satisfaction to a large extent are influencing the higher education, leaving no option for institutions but to accept students as customers (Hill, 1995; Shank, Walker, \& Hayes, 1995). Hence considering students as outlet to know about the service quality in higher education is meaningful (Anthiyaman, 1997).

\subsection{Culture (CUL) and Higher Education}

Saudi Arabia the land of Islam's birth place, hence every aspect of life is influenced by the principles of Islam, and higher education is no exception to this. There are various issues of Gulf culture embedded into education system including higher education. Language of instruction, communication and content is preferred in Arabic (Abuhamdia, 1988). There are courses in English language available; preference is given if some or all of the components of learning are available in Arabic. The teaching methodology has deep roots of Gulf principles and schooling, kuttab and madrassa in which halaga type, that is religious gathering kind of teaching style is practiced. The teacher student environment is one way, where a teacher lectures and students to be like statue, hence interaction between the teacher and student is less Szyliowicz (1973, p. 51). Baker, 1997, p. 246 has discussed the issue in which class room structure is teacher centric, where rules and regulations are strictly followed. These rules even describe how a student should ask questions to teachers and adopt, listen more talk less principle. In the Gulf region teaching methodology of some institutions encourages teacher student discussion (Cassidy \& Miller, 2002; Rugh, 2002). Students are not allowed to question the teacher rather they can seek clarification on certain concept. As per the religious principles a teacher who imparts knowledge is absolute authority in the class room, hence student to be treated as consumers or rather consumerism in higher education (Hill, 1995) in Saudi Arabia is a distant dream. Designing a student centric pedagogy is difficult to be introduced in Saudi education environment which is dominated by teacher centric ideology (Jamjoon, 2009, pp. 7-8).

The acceptance of globalization by large number of nations has given way for accepting English as the common language of instruction in higher education (Picard, 2007). In the case of Saudi Arabia, English was included in the primary schools in 2003 (Elyas, 2008). Teaching English or even talking English is treated as against the Gulf principles (Azuri, 2006, p. 1). Instruction in Arabic is given top priority and felt more comfortable by teachers and institutions. English is seen as something unwanted or forced upon them Abuhamdia (1988, p. 42). Teaching English and courses in English is a challenge to the teacher (Al-Hazmi, 2003; Syed, 2003; Picard, 2007; Elyas, 2008).

Cassidy and Miller, (2002) in their study have identified that rote learning and memorization is used as the method of learning in higher education in Arab nations. This method of learning hinders problem solving skills and theoretical concepts being applied to practical situations. In another study by (Rugh, 2002) has identified that the learning system in Arab institutions is designed teacher centric and memorization, which does not enable 
the students with skills needed for employability in the present competitive environment. (Al-Hazmi, 2003; Syed, 2003) in their study have opined that quantitative infrastructure facilities like libraries, computer labs, class rooms, canteens, teaching technologies, faculty members have been added in enormous numbers, but qualitatively the teaching environment need to be upgraded to a large extent may be completely. The educational system needs a complete turnaround; the change should start from foundations itself (Rugh, 2002; Azuri, 2006). Contrary to the immediate past, some Arab countries including Saudi Arabia have adopted western pedagogy and curriculum at higher education level (Cassidy \& Miller, 2000; Picard, 2007).

\section{Research Methodology}

The objective of this study is to compare CUL-HEdPERF scale with SERVPREF and HEdPERF scales. Further the study also emphasizes the most appropriate scale to measure the service quality of higher education in Gulf cultural context. Scale development and testing process developed by Timothy R. Hinkin (1995) was adopted. Stage one - item generation, stage two - scale development, stage three - scale evaluation.

STAGE ONE: Item generation -this study used deductive method to identify the items. The focus of this study is service quality in higher education. Sufficient literature related to all the conceptual and operational parameters had been considered to identify the items. Deductive method suggests, items to a new scale to be acquired from the existing scales which are tested well in another universe, hence HEdPERF and SERVPERF scales were considered for item generation idea.

STAGE TWO: scale development - in this stage it is suggested that, questionnaire or instrument development, scale used, pre-testing, sampling method used, sample size and other related issues were to be addressed. Three different questionnaires were developed with optimum number of items. Questionnaire one- CUL-HEdPERF had two sections; first section had 6 questions pertaining to student's personal details. Second section consisted of 39 item scale of which 19 items reflecting Gulf cultural and institution level aspects related to higher education and 12 items from HEdPERF (Firdaus, 2006a) scale and 8 items from original SERPERF (Cronin \& Taylor, 1992) were adopted and modified.

Questionnaire two had 41 items, the original scale of HEdPERF (Firdaus, 2006a). Questionnaire three had 22 items, the original scale of SERVPERF (Cronin \& Taylor, 1992). Coefficient alpha levels will be higher if the scale uses points between 3 and 10. Specifically higher the points between the said range, higher will be the alpha levels. Hence a seven point Likert type scale was used where 1 indicated strongly disagree and 7 indicated strongly agree. As theorised by deductive principle to use a small group of sample experts or the study sample elements in finalizing the scale items, a pilot test was done on the initial questionnaire with the help of 25 students. Five Business Administration colleges from five Universities and five students from each college were selected to administer the initial questionnaire. Culture being one of the key subjects of questionnaire it was felt better to equally spread the study among elements right from the initial questionnaire. Some valid suggestions came from students with regards to language usage and sentence formation. In Arabic some words have up to thousand synonyms, hence conversion of any scale designed in English has to be converted into Arabic and then again into English. For this process the study had taken help of Arabic language professor who had sound knowledge of English. For the final collection of data, the same Business Administration colleges from five Universities were taken into consideration. Data collection took two months from March to May 2014. This timing is suitable and ideal for data collection in Saudi Arabia. To match the results of exploratory and confirmatory factor analysis, items to respondent's ratio should be between 1:4 and 1:10. In this study 150 questionnaires were distributed in five universities making a total of 750 , since the questionnaire was in Arabic and was well explained to the elements only two percent of questionnaires were found to be not useful that is fifteen questionnaires and the remaining 735 questionnaires were further used for data analysis. Unidimentionality, reliability, validity and explained variance of service quality were used to test the fitness of each scale.

\section{Result Analysis and Discussion}

For the data analysis structural equation modelling by Karl J“oreskog (2002) with the help of LISREL 8.54 was used for analysis. (LISWIN32.EXE) a 32-bit Windows application developed by Scientific Software International Inc. (SSI) was used. The LISREL manual (J"oreskog et al., 2001) was referred command language. Owing to its easy usage PRELIS was used for normal score transforms. Descriptive analysis was performed using the same. SIMPLIS was used for multivariate analysis since it was found that SIMPLIS code writing is simpler than LISREL command language. For the purpose of this study, EFA, CFA, goodness of fit indices including the relative likely ratio, regression, analysis of variance were performed using SIMPLIS code. 


\subsection{Test for Reliability and Unidimentionality}

To assess the goodness of fit, each scale was considered independently. Exploratory factor analyses were used to know the reliability of scales respectively (Ford et al., 1986). Table 2 exhibits the alpha values. For performing exploratory factor analysis, principal component analysis and varimax as the rotation method was used identifying three dimensions with factor loadings (refer Table 3) since this method was used in $33 \%$ of the studies (Timothy, 1995). Extension to this a confirmatory factor analyses was conducted and results are detailed in the following sections.

\subsection{Test for Reliability}

To test the internal consistency of scales Cronbach's alpha values as suggested by (Nunally, 1978) were used. Each scale consisted of several items. Students gave responses for three scales, to address data inconsistency scale reliability was checked. Research world is well aware the alpha values range between 0 and 1 . This study fixed a threshold value of 0.6 for each dimension to be accepted as reliable. Table 2 shows the comparison among three scales CUL-HEdPERF dimension "Issues related to Gulf culture" scoring the highest with 0.932 and remaining two dimensions also with high alpha values. HEdPERF scale ranged between 0.708 and .899 , with one dimension "Non-Academic aspects" scoring less than the threshold value. SERVPREF scale ranged between 0.701 and .843 , with one dimension "Empathy" scoring less than the threshold value.

Table 2. Reliability values

\begin{tabular}{|c|c|c|c|}
\hline Dimensions & CUL-HEdPERF & HEdPERF & SERVPREF \\
\hline Tangibles & & & 0.843 \\
\hline Reliability & & & 0.701 \\
\hline Responsiveness & & & 0.811 \\
\hline Assurance & & & 0.782 \\
\hline Empathy & & & 0.428 \\
\hline Non-Academic aspects & & 0.407 & \\
\hline Academic aspects & & 0.834 & \\
\hline Reputation & & 0.708 & \\
\hline Access & & 0.842 & \\
\hline Program issues & & 0.899 & \\
\hline Issues related to Gulf culture* & 0.932 & & \\
\hline $\begin{array}{l}\text { Professionalism in executing issues related to academic and } \\
\text { non-academic activities* }\end{array}$ & 0.904 & & \\
\hline Issues at institution level* & 0.892 & & \\
\hline
\end{tabular}

Note. Cronbach's $\alpha$ coefficient values; *Explanation to this factors is provided in the main document.

The description of three factors is as follows:

Issues related to Gulf culture: All the items/variables which reflect the Gulf cultural value system and major stakeholders of higher education consider these issues to be very important and expect them to be blended within the whole system. Professionalism: All the items/variables which needs the demonstration of professionalism by both academic and administrative staff in achieving academic and administrative excellence. Issues at institution level: All the items/variables which are taken care at institution level, these issues require mostly direct involvement of management of the institution. The new three dimensions derived are from a blend of HEdPERF original scale and Gulf cultural context issues where issues related to academic and non-academic activities are from previous scales, issues related to Gulf culture and issues related to institution level are the new dimensions extended by this study.

\subsection{Inter-Scale Correlation}

Correlation technique helped to analyse the inter-item/scale relationship. It helped this study to de-compose the items leading to formation of composite item set which represent scale which gives more approximation of 
results close to universe. The Table 4 reveals the correlation values among three scales of service performance measurement. The performance score clearly indicates that CUL-HEdPERF drives higher correlation with all the three factors. HEdPERF finds little lower correlation with other two scales. SERVPREF has lower positive correlations. Responses to CUL-HEdPERF generate higher correlations to factors indicating higher scale validity. Past research also indicate a positive relationship between scales and factors, the only variation of this study's results are higher values obtained by the new scale.

Chi square was used to measure the difference between sample and its estimated matrices or data fitting the proposed model scale (Cohen, 1969; Gerbing \& Anderson, 1988; Hinkin \& Schriesheim, 1989). If chi square is found to be significant when compared to its degrees of freedom, the difference exists and when found to be insignificant, proves proposed model scale to be fit (Cohen, 1969; Gerbing \& Anderson, 1988). Exact fit for unidimentionality of a scale is measured in this study by relative likelihood ratio between chi-square and its degrees of freedom, Table 5 shows the result CUL-HEdPERF 1.43, HEdPERF 2.98, SERVPREF 3.62 indicates that the values are below five achieving acceptable fit. CUL-HEdPERF with 1.43 is lowest and achieving high fitness for unidimentionality among three scales. RMSEA score of CUL-HEdPERF with 0.017 less than 0.05 indicating a close fit to the data, HEdPERF with 0.062 ranges between 0.05 and 0.08 indicating a fair fit and SERVPREF 0.089 ranges between 0.08 and 1 indicating a poor fit (Hoelter, 1983). Goodness of fit indices GFI, AGFI, CFI, NNFI, and IFI have values on higher side on a range of zero to one for CUL-HEdPERF indicating a stronger fitness (Hoelter, 1983) and HEdPERF and SERVPREF are with lower values.

Table 3. Items to factors/dimensions with loadings

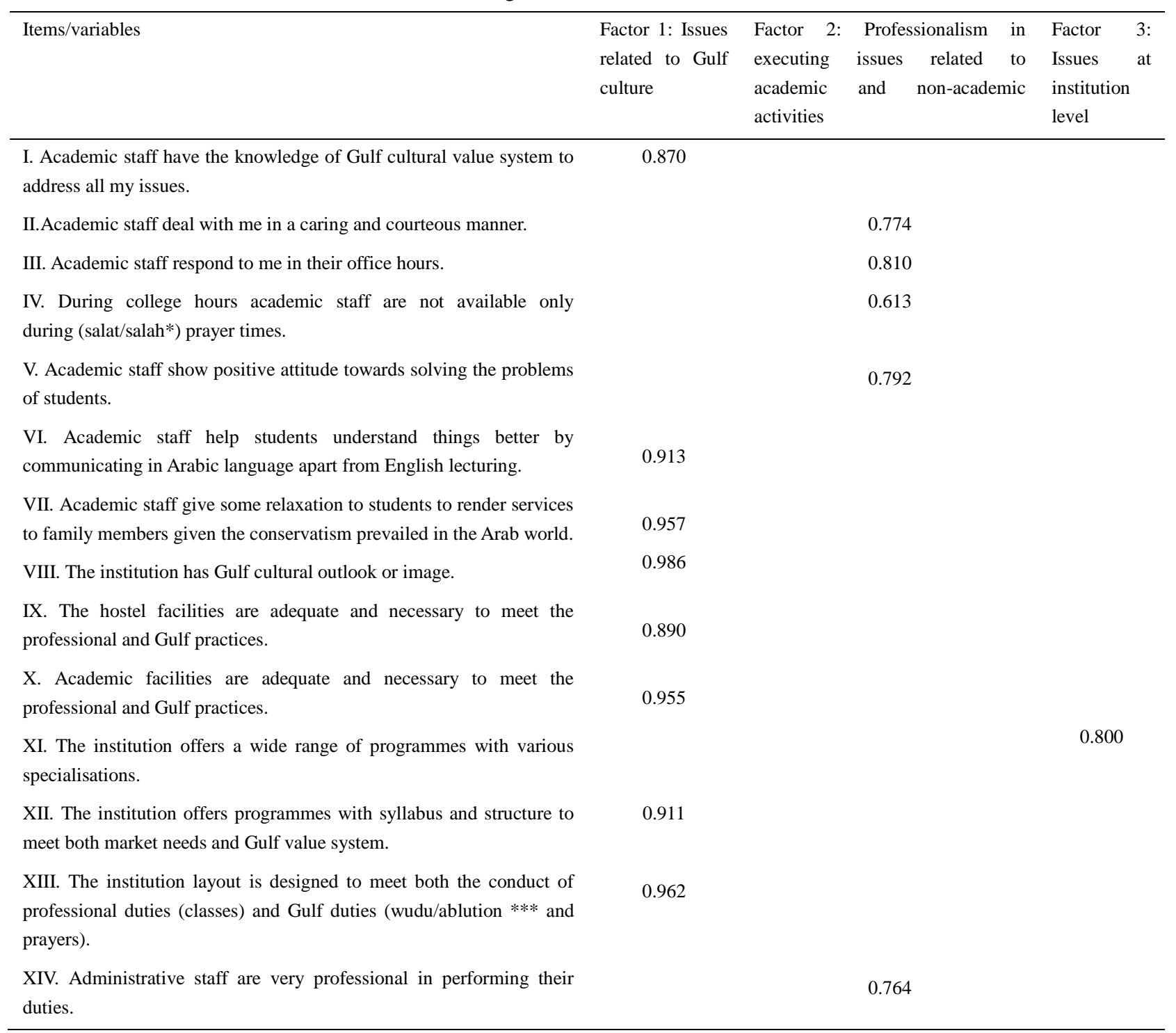


XV. Administrative staff show positive attitude in solving the student

issues.

XVI. Administration offices keep accurate and error free records.

XVII. Administrative staff have never delayed in paying student monthly allowances.

XVIII. Administrative staff are technically educated and trained to run the intranet (edugate) which allows students to access most of the needed information.

XIX. Academic staff keep all the material/content and are prompt in updating the information on intranet(LMS**).

XX. Academic staff, Adminstrative staff, students and others are all equal and derive same respect as per Gulf values.

0.907

XXI. Consumerism is a part of Institutions philosophy where students are treated as consumers.

XXII. Institution provides mentoring services using academic staff which are very useful for the students in both personal and professional fronts.

XXIII. Institution provides quality health services to all students at free of cost.

XXIV. Institution discourages setting up of student's union as this is against the principles of Gulf culture.

XXV. Rules, regulations and procedures of routine and non-routine nature are easy to understand and comply.

XXVI. The lecture sessions, student evaluation, co-curricular activities and all are faculty centric and not student centric.

XXVII. Institution takes initiative to do improvements upon students feeback each semester.

XXVIII. As all the students come by their individual cars, institution provides adequate parking facilities.

XXIX. All the students respect the mandatory common dress code wearing throbs during college hours as per Gulf culture.

XXX. Institution takes sufficient effort in providing the job opportunities in both government and private sector companies.

XXXI. Institution never discourage students communicating in Arabic language with Academic staff, Administrative staff and with fellow students.

XXXII. Institution takes great effort in providing the needed literature to students like books, journals, magazines, newspapers, information flyers, information kiosks etc. in Arabic and English language.

XXXIII. The institution provides services within reasonable/expected time frame.

XXXIV. Administrative staff provide caring and individual attention.

Note. * salat/salah is prayer offered to almighty.

** LMS is Learning Management System.

***wudu/ablution is cleaning oneself before offering the prayer. 
Table 4. Inter-correlation between scales

\begin{tabular}{lccc}
\hline Correlation & CUL-HEdPERF & HEdPERF & SERVPREF \\
\hline CUL-HEdPERF & 0.94 & 0.71 & 0.77 \\
HEdPERF & 0.24 & 0.65 & 0.44 \\
SERVPREF & 0.21 & 0.32 & 0.40
\end{tabular}

Note. *correlations significant at $\alpha=0.01$.

\subsection{Weightage of Dimensions across Scales}

Each scale has different service quality level. It is logical each scale explains a different variation in service quality. Regression analysis was done for student perception on service quality for the dimensions across three scales CUL-HEdPERF, HEdPERF and SERVPREF. Table 6 display the $\mathrm{R}^{2}$ values. These values establish CUL-HEdPERF

Table 5. Multi-dimensional analysis of scales

\begin{tabular}{lcccc}
\hline & Null Model & CUL-HEdPERF & HEdPERF & SERVPREF \\
\hline Chi-square $\left(x^{2}\right)$ at $\mathrm{p}=0.05$ & 5861 & 1247 & 2722 & 2962 \\
Degree of freedom $(\mathrm{df})$ & 653 & 872 & 940 & 817 \\
Relative likelihood ratio $\left(x^{2} / \mathrm{df}\right)$ & 8.97 & 1.43 & 2.98 & 3.62 \\
RMSEA & 0.118 & 0.017 & 0.062 & 0.089 \\
NNFI & 0.427 & 0.845 & 0.510 & 0.329 \\
IFI & 0.372 & 0.877 & 0.621 & 0.331 \\
NFI & - & 0.912 & 0.556 & 0.518 \\
CFI & 0.400 & 0.901 & 0.731 & 0.660 \\
AGFI & 0.397 & 0.828 & 0.831 & 0.571 \\
\hline
\end{tabular}

Table 6. Regression and ANOVA analysis

\begin{tabular}{|c|c|c|c|}
\hline Dimensions & CUL-HEdPERF & HEdPERF & SERVPREF \\
\hline \multirow[t]{2}{*}{ Intercept } & 1.41 & 4.76 & 3.75 \\
\hline & $0.15 *$ & $0.24 *$ & $0.32 *$ \\
\hline \multirow[t]{2}{*}{ Tangibles } & & & 14.52 \\
\hline & & & $0.32 *$ \\
\hline \multirow[t]{2}{*}{ Reliability } & & & -0.43 \\
\hline & & & $0.14 *$ \\
\hline \multirow[t]{2}{*}{ Responsiveness } & & & 0.32 \\
\hline & & & $0.27 * *$ \\
\hline \multirow[t]{2}{*}{ Assurance } & & & 0.29 \\
\hline & & & $0.13 *$ \\
\hline \multirow[t]{2}{*}{ Empathy } & & & 0.04 \\
\hline & & & 0.11 \\
\hline \multirow[t]{2}{*}{ Non-Academic aspects } & & 0.41 & \\
\hline & & $0.26 *$ & \\
\hline \multirow[t]{2}{*}{ Academic aspects } & & 0.02 & \\
\hline & & 0.17 & \\
\hline \multirow[t]{2}{*}{ Reputation } & & -0.21 & \\
\hline & & $0.10 *$ & \\
\hline
\end{tabular}




\begin{tabular}{|c|c|c|c|}
\hline \multirow[t]{2}{*}{ Access } & & 0.57 & \\
\hline & & $0.27 * *$ & \\
\hline \multirow[t]{2}{*}{ Program issues } & & 0.74 & \\
\hline & & $0.27 * * *$ & \\
\hline \multirow[t]{2}{*}{ Issues related to Gulf culture } & 0.25 & 0.42 & \\
\hline & $0.14 *$ & $0.29 *$ & \\
\hline Professionalism in executing issues related to academic and & 0.14 & 0.61 & \\
\hline non-academic activities & $0.09 * * *$ & $0.14 *$ & \\
\hline \multirow[t]{2}{*}{ Issues at institution level } & 0.21 & 0.17 & \\
\hline & $0.09 *$ & 0.12 & \\
\hline $\mathrm{R}^{2}(\%)$ & 52 & 41 & 27 \\
\hline $\mathrm{F}$ & 22.09 & 46.77 & 17.32 \\
\hline $\mathrm{P}$ & 0.00 & 0.00 & 0.00 \\
\hline
\end{tabular}

Note. Statistical significance $0.01^{*} ; 0.05^{* *} ; 0.10^{* * *}$.

Explaining 52\% of variance followed by HEdPERF with $41 \%$ and SERVPREF with $27 \%$. The results of the analysis reveal the service quality dimensions of CUL-HEdPERF scale are statistically significant. Comparatively the service quality dimension of HEdPERF "Non-Academic aspects" and the dimension "Empathy" from SERVPREF are not statistically significant. Previous studies done by (Firdaus, 2006b; Brochado, 2009) have proved similar trend of results where the modified scales HEdPERF and Modified SERVPREF in their respective study explained higher variation than other scales.

\section{Conclusions}

Under the pretext that there are dispersions across geographical, socio-political, cultural, religious, lifestyle and technological aspects in the globe, a scale developed at a place under certain conditions may not be applied to measure the elements in other places. This indicates a scale's applicability or generalization at a universal level is questionable. There are scales which were developed and their applicability is nearly accepted universally SERVQUAL (Parasuraman, 1988) and SERVPERF (Cronin \& Taylor, 1992). There had been several scales developed based on the above two scales to match a particular sector. In a similar direction this study concluded CUL-HEdPERF to measure the quality of higher education in Gulf cultural context with an extensive literature review, depth interviews, expert opinions and pilot test.

Firdaus (2006b) in his study had identified that the generic scales via SERVQUAL (Parasuraman, 1988), SERVPERF (Cronin \& Taylor, 1992) exhibit superiority in measuring the service quality of general nature. He is also of opine that industry specific scales are needed like HEdPERF (Firdaus, 2006a) which was designed for measuring the service quality in higher education. This study tested successfully three scales CULHEdPERF, HEdPERF and SERVPERF for unidimentionality, reliability, validity and explained variance of service quality. It can be said that the issue was not exactly to prove a scale's superiority, rather to know a scale's fitness to a particular situation and time.

Firstly significant results were achieved using Bartlett test of sphericity with chi square $(95, \mathrm{~N}=735)=17.42,(\mathrm{p}=$ 0.00) and Kaiser-Meyer-Olkin (KMO) measure for sampling adequacy has shown an inter-correlation value of 0.94 among the variables for CUL-HEdPERF which is quiet high (Ford, MacCallum, \& Tait, 1986) indicating suitability for factor analysis. Owing to the need of achieving sample size adequacy to be taken care of in testing the new and existing scale, sample size adequacy was achieved by the criterion of crossing the requirement of sample size greater than the number of statements multiplied by five. It can be concluded that a total sample size of 735 indicates a good sample size adequacy. Since study involved in testing the existing scale, sample size adequacy was taken care off.

For better internal consistency and reliability, item loadings were set at a maximum of .70. Many researchers believe that this will increase the construct validity. Contrarily there were studies which considered items loadings as low as .30. Many researchers believe that item loading should be at least .60, this will eliminate quite a number of items form the scale effecting reliability and validity of the measure, but on the other hand it will improve the overall construct validity. Especially Nunnally (1978) has recommended 0.6 for reliability and internal consistency of a scale or an independent construct which is adopted into a new scale development or 
modification of an existing scale to suit to a particular study context. In this study the items which had significance at $p=0.01$ with a factor loading of 0.7 have been considered. The results concluded with 5 items having factor loadings less than 0.7 were withdrawn bringing the total items from 39 to 34 and further proceeded for confirmatory factor analysis assessing unidimentionality, reliability and validity.

The outcome of Factor analysis indicated three dimensions via "Issues related to Gulf culture" items which loaded within this dimension had described local cultural aspects influencing the service quality in higher education. "Professionalism", items which loaded within this dimension were taken from the previous scale and they included academic and administrative issues. "Issues at institution level", items which loaded within this dimension relate to management issues, which are addressed by the decision makers at institution level.

Multi-dimensional analysis; minimum likely-hood ratio, RSMEA, NNFI, IFI, NFI, CFI, AGFI all directed towards supporting unidimentionality of the three scales with better results for CUL-HEdPERF. Finally $\mathrm{R}^{2}$ explained 52\% of variation in CUL-HEdPERF with positive acceptance by variance analysis using F. It can be concluded that to measure the service quality in higher education in gulf region, CUL-HEdPERF is more suitable scale than others.

\section{Acknowledgments}

The Researcher would like to thank Marketing Department, Quality and Accreditation unit and Deanship of Scientific Research at King Saud University represented by the Research Centre, College of Business Administration for supporting this research non-financially.

\section{References}

Athiyaman, A. (1997). Linking student satisfaction and service quality perceptions: The case of University education. European Journal of Marketing, 31(7), 528-40. http://dx.doi.org/10.1108/03090569710176655

Angell, R. J. M., Heffernan, T. W., \& Megicks, P. (2008). Service quality in postgraduate education. Quality Assurance in Education, 16(3), 236-254. http://dx.doi.org/10.1108/09684880810886259

Al-Hazmi, S. (2003). EFL teacher preparation programs in Saudi Arabia: Trends and challenges. TESOL Quarterly, 37(2), 341-351. http://onlinelibrary.wiley.com/doi/10.2307/3588509

Azuri, L. (2006). Debate on reform in Saudi Arabia. Inquiry and Analysis Series, No. 294, pp. 1-6. Retrieved from http://www.memri.org/report/en/0/0/0/0/0/254/1787.htm

Abuhamdia, Z. (1988). Speech and language unity: Arabic as an integrating factor in the politics of Arab Integration (pp. 33-53). New York, NY.

Baker, C. (1997). Constructing and reconstructing classroom literacies in constructing critical literacies. Cres skill, NJ: Hampton Press.

Brochado, A. (2009). Comparing alternative instruments to measure service quality in higher education. Quality Assurance in Education, 17(2), 174-190. http://dx.doi.org/10.1108/09684880910951381

Cassidy, T., \& Miller, M. (2002). Higher education in the Arab states: Responding to the challenges of globalization (Unpublished $\mathrm{PhD}$ ). Harvard University, Cambridge, MA.

Cohen, J. (1969). Statistical power analysis for the behavioral sciences. New York: Academic Press.

Cronin, J., \& Taylor, S. (1992). Measuring service quality: A re-examination and extension. Journal of Marketing, 56, 55-68. http://www.jstor.org/stable/10.2307/1252292

Cuthbert, P. F. (1996). Managing service quality in higher education: Is SERVQUAL the answer? Managing Service Quality, 6(2), 11-16. http://dx.doi.org/10.1108/09604529610109701

Department for Education. (1993). Charter for higher education. London: HMSO.

Elyas, T. (2008). The attitude of American English within the Saudi education system. Novitas-ROYAL (Research on Youth and Language), 2(1), 28-48.

Firdaus, A. (2006a). The development of HEdPERF: A new measuring instrument of service quality for the higher education sector. International Journal of Consumer Studies, 30(6), 569-581. http://dx.doi.org/10.1111/j.1470-6431.2005.00480.x

Firdaus, A. (2006b). Measuring service quality in higher education: Three instruments compared. International Journal of Research and Method in Education, 29(1), 71-89. http://dx.doi.org/10.1108/02634500610641543

Firdaus, A. (2004). The development of HEdPERF: A new measuring instrument of service quality for higher 
education sector. Paper presented at the Third Annual Discourse Power Resistance Conference: Global Issues Local Solutions, University of Plymouth, Plymouth, 5-7 April.

Ford, J. K., MacCallum, R. C., \& Tait, M. (1986). The application of exploratory factor analysis in applied psychology: A critical review and analysis. Personnel Psychology, 39, 291-314. http://dx.doi.org/10.1111/j.1744-6570.1986.tb00583.x

Ginns, P., Prosser, M., \& Barrie, E. (2007). Student's perceptions of teaching quality in higher education: The perspective of currently enrolled students. Studies in Higher Education, 32(5), 603-15. http://dx.doi.org/10.1080/03075070701573773

Gerbing, D. W., \& Anderson, J. J. (1988). An updated paradigm for scale development incorporating unidimentionality and its assessment. Journal of Marketing Research, 25, 186-92. http://dx.doi.org/10.2307/3172650

Hill, F. M. (1995). Managing service quality in higher education: the role of student as primary consumer. Quality Assurance in Education, 3(3), 10-21. http://dx.doi.org/10.1108/09684889510093497

Hinkin, T. R., \& Schriesheim, C. A. (1989). Development and application of new scales to measure the French and Raven bases of social power. Journal of Applied Psychology, 74, 561-567. http://dx.doi.org/10.1037/0021-9010.74.4.561

Hoelter, J. W. (1983). The analysis of covariance structures: Goodness-of-fit indices. Sociological Methods and Research, 11, 325-344. http://dx.doi.org/10.1177/0049124183011003003

Jamjoon, M. I. (2009). Female Islamic studies teachers in Saudi Arabia: A phenomenological study. Teaching and Teacher Education, $X X, 1-12$.

Joreskog, K., \& Sorbom, D. (2002). PRELIS 2: User reference guide. Scientific Software International, Lincolnwood.

Joreskog, K., Sorbom, D., Du Toit, S., \& Du Toit, M. (2001). LISREL 8: New Statistical Features. Scientific Software International, Lincolnwood.

Nunally, C. J. (1978). Psychometric theory. New York, NY: McGraw-Hill.

Oldfield, M. S., \& Baron, S. (2000). Student perceptions of service quality in a UK university business and management faculty. Quality Assurance in Education, 8(2), 85-95. http://dx.doi.org/10.1108/09684880010325600

O’Neil, M., \& Palmer, A. (2004). Importance-performance analysis: a useful tool for directing continuous quality improvements in higher education. Quality Assurance in Education, 12(1), 39-52. http://dx.doi.org/10.1108/09684880410517423

O’Neil, M., \& Wright, C. (2002). Service quality evaluation in the higher education sector: An empirical investigation of student perceptions. Higher Education Research and Development, 21(1), 23-40. http://dx.doi.org/10.1080/07294360220124639

Parasuraman, A., Zeithaml, V., \& Berry, L. L. (1985). A conceptual model of service quality and its implications for future research. Journal of Marketing, 49, 41-50. http://www.jstor.org/stable/ 10.2307/i253395

Parasuraman, A., Berry, L. L., \& Zeithaml, V. (1991). Refinement and reassessment of the SERVQUAL scale. Journal of Retailing, 57(3), 25-48.

Parasuraman, A., Valarie, A., Zeithaml, V., \& Berry, L. L. (1988). SERVQUAL: A multiple-item scale for measuring consumer perceptions of service quality. Journal of Retailing, 64(1), 12-40. http://psycnet.apa.org/psycinfo/1989-10632-001

Parasuraman, A., Zeithaml, V., \& Malhotra, A. (2005). E-S-QUAL: A multiple-item scale for assessing electronic service quality. Journal of Service Research, 7(3), 213-33. http://dx.doi.org/10.1177/1094670504271156

Picard, M. Y. (2007). Academic English right from the start: A critical realist study of the way academic English is constructed at a Gulf University ( $\mathrm{PhD}$ thesis). Rhodes University, Grahamstown. Retrieved from http://eprints.ru.ac.za/907/

Rugh, W. (2002). Arab education: Tradition, growth and reform. The Middle East Journal, 56(3), 396-414. Retrieved from http://www.jstor.org/stable/4329785

Stafford, M. R. (1999). Assessing the fit and stability of alternative measures of service quality. Journal of Applied Business Research, 15(2), 13-31. 
Syed, Z. (2003). The sociocultural context of English language teaching in the Gulf. TESOL Quarterly, 37(2), 337-40. http://dx.doi.org/10.2307/3588508

Szyliowicz, J. S. (1973). Education and modernization in the Middle East. London: Cornell University Press.

Shank, M. D., Walker, M., \& Hayes, T. (1995). Understanding professional service expectations: Do you know what our students expect in a quality education? Journal of Professional Service Marketing, 13(1), 71-89. http://dx.doi.org/10.1300/J090v13n01_08

Sohail, M. S., \& Shaikh, N. M. (2004). Quest for excellence in business education: A study of service quality. International Journal of Educational Management, 18(1), 58-65. http://dx.doi.org/10.1108/09513540410512163

Tan, K. C., \& Kek, S. W. (2004). Service quality in higher education using an enhanced SERVQUAL approach. Quality in Higher Education, 10(1), 17-24. http://dx.doi.org/10.1080/1353832242000195032

Timothy, R. H. (1995). A review of scale development practices in the study of organizations. Journal of Management, 21(5), 967-988. http://dx.doi.org/10.1177/014920639502100509

Yanhong, R., \& Kaye, V. (1998). A case study for comparing two service quality measurement approaches in the context of teaching in higher education. Quality in Higher Education, 4(2), 103-13. http://dx.doi.org/10.1080/1353832980040202

\section{Copyrights}

Copyright for this article is retained by the author(s), with first publication rights granted to the journal.

This is an open-access article distributed under the terms and conditions of the Creative Commons Attribution license (http://creativecommons.org/licenses/by/3.0/). 